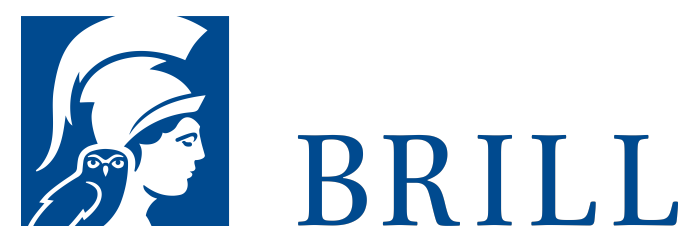

\title{
Ossip Mandelstams letzte Jahre
}

Verfemung, Verbannung und Tod eines Dichters $193^{2-38}$

Author: Pavel Nerler (Polian)

Der russisch-jüdische Dichter Ossip Mandelstam, 1891 in Warschau geboren, ist einer der bedeutendsten Lyriker des 20. Jahrhunderts. Sein tragisches Schicksal im Stalinismus steht exemplarisch für das Los der Intellektuellen und Künstler in den Diktaturen der Moderne.

Der extrem sensible, eigensinnige, demonstrativ individualistische Mandelstam war zwar in der Sowjetunion bis hin zu Stalin selbst als herausragender Poet anerkannt. Letztlich aber wurde dem Dichter seine Unangepasstheit zum Verhängnis: Nach einem Epigramm auf Stalin in das Mahlwerk von Miliz und Geheimdienst geraten, wurde Mandelstam bestraft, verbannt, rehabilitiert, wieder verhaftet und am Ende in den sibirischen Gulag deportiert, wo er durch die Strapazen des Lagerlebens umkam. Pavel Nerler, wohl der beste MandelstamKenner der Gegenwart, hat in langjährigen Recherchen aus den Archiven unbekanntes Material zusammengetragen und kann so die letzten Lebensjahre des Dichters in erschütternder Anschaulichkeit schildern: die Intrigen der Kollegen, aber auch die Versuche ihn in die Sowjetgesellschaft einzubinden, die Verhöre, die Widrigkeiten der Verbannung, die psychischen Zusammenbrüche und am Ende den Tod in Sibirien.

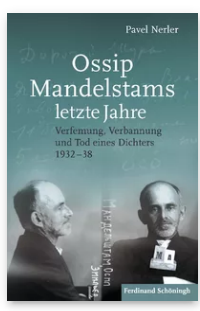

Pages: 360 Seiten, 32 farb.

Abb.

Language:

German

Subjects:

Modern History, History

Publisher: Brill|

Schöningh

E-Book (PDF)

Released online: o5 Oct 2017

ISBN: 978-3-

657-78530-8

List price

Hardback

Publication date: 29 Sep 2017

ISBN: 978-3506-78530-5 List price 
Pavel Nerler ist Gründer und Vorsitzender der MandelstamGesellschaft (Moskau) und Direktor des Mandelstam-Zentrums in der High School of Economics in Moskau. Autor und Mitherausgeber zahlreicher Publikationen über Ossip Mandelstam. Für das vorliegende Buch konnte er auch auf Erkenntnisse aus seinen Gesprächen mit Mandelstams Witwe und Freunden des Dichters zurückgreifen.

For more information see brill.com

Order information: Order online at brill.com +44330 333 o049 | customerservices@brill.com Submission information: brill.com/authors

Titles published by Brill | Fink, Brill | mentis or Brill | Schöningh: +49(o)71 5413279216 | brill@brocom.de 